\title{
PRAKTIKALITAS LEMBAR KERJA SISWA PADA PEMBELAJARAN MATEMATIKA MATERI STATISTIKA
}

\author{
Eva Roliza ${ }^{1}$, Rezky Ramadhona ${ }^{2}$, Linda Rosmery $\mathrm{T}^{3}$ \\ 1evaroliza07@gmail.com \\ ${ }^{1,2,3}$ Universitas Maritim Raja Ali Haji \\ 2018
}

\begin{abstract}
Abstrak
Tujuan dari penelitian ini adalah untuk mengembangkan Lembar Kerja Siswa pada pembelajaran matematika materi statistika yang praktis. Model penelitian ini menggunakan model ADDIE, yaitu tahap analisis, tahap perencanaan, tahap pengembangan, tahap implementasi, dan tahap evaluasi. Penelitian ini dibatasi pada tahap implementasi yaitu untuk melihat kepraktisan Lembar Kerja Siswa diuji coba secara terbatas. Berdasarkan hasil uji praktikalitas Lembar Kerja Siswa dengan melalui tiga data penilaian, yaitu pertama data observasi dengan rata-rata $71 \%$ kategori baik, kedua data angket respon guru dengan rata-rata $75 \%$ kategori baik, dan ketiga data angket respon siswa dengan rata-rata $84 \%$ katagori baik.
\end{abstract}

Kata Kunci: Praktikalitas, Lembar Kerja Siswa, tahap implementasi, Materi Statistika

\begin{abstract}
The purpose of this study was to develop a practical Student Worksheet on mathematics learning within statistics material. The research method was research and development by using ADDIE namely the analysis stage, planning satge, development stage, and implementation and evaluation stages. This study was limited to the implementation stage which was conducted to look at the practicality of Student Worksheet tested on a limited basis. Based on the test results, practicality of Student Worksheet through three assessment data: the first observation data with an average $71 \%$ in a good category, the second data questionnaire responses of teachers with an average $75 \%$ in a good category, and the third data questionnaire responses of students with an average $84 \%$ in a good category.
\end{abstract}

Keywords: practicalities, Student Worksheet, implementation phase, Creative Statistics

\section{Pendahuluan}

Matematika merupakan salah satu pembelajaran yang berperan penting dalam pendidikan. Pembelajaran matematika merupakan suatu mata pelajaran dalam pelaksanaan pendidikan yang dipelajari anak-anak mulai dari tingkat Sekolah Dasar (SD) sampai Sekolah Menengah

Atas (SMA) serta perguruan tinggi. Namun pelajaran matematika saat ini masih menjadi momok, karena siswa menggangap pelajaran matematika adalah pelajaran yang kurang disenangi, sukar, sangat membosankan dan mengakibatkan rendahnya hasil belajar siswa. 
JURNAL GANTANG. Maret 2018; III(1): 41 - 45

p-ISSN. 2503-0671

e-ISSN. 2548-5547

Pembelajaran matematika Sekolah Menengah Kejuruan Negeri Tanjungpinang sudah mengacu pada kurikulum 2013. Sebagai bentuk pembelajaran kurikulum 2013 guru di tuntut untuk menjadi fasilitator bagi siswa. Guru harus bisa membuat siswa aktif dalam proses belajar dan menciptakan pembelajaran efektif melalui inovasi model, dan metode pembelajaran yang bervariasi.

Dalam permasalahan di Sekolah terdapat beberapa permasalahan seperti masalah pertama kurangnya buku pegangan matematika untuk siswa, karena setiap habis jam pelajaran buku tersebut dikembalikan lagi ke perpustakaan. Sehingga membuat siswa kesulitan memahami materi dan belajar tambahan diluar sekolah. Masalah kedua, guru masih menggunakan buku-buku dari penerbit dan buku sumbangan dari pemerintah, serta guru kurang memberikan panduan tambahan bahan ajar seperti Lembar Kerja Siswa. Sehingga siswa hanya mengandalkan materi yang dipaparkan oleh guru dan membuat pembelajaran cenderung hanya berfokus pada guru. Padahal dalam pembelajaran kurikulum 2013 guru harus membuat pembelajaran lebih menarik agar siswa memperoleh pengalaman sendiri.

Oleh karena itu, pembelajaran sangat membutuhkan bahan ajar tambahan seperti Lembar Kerja Siswa. Menurut Prastowo (2015: 204) Lembar Kerja Siswa merupakan bahan ajar cetak yang berupa lembar-lembar kertas yang berisi Lembar Kerja Siswa dengan uji coba secara terbatas. Lembar Kerja Siswa (LKS) memungkinkan setiap siswa dapat menuangkan ide-ide dan pendapatnya dalam mengkritisi permasalahan matematika (Astuti, et al, 2017).

Menurut Nieveen (1999) dalam (Rochmad 2012) menyatakan bahwa mengukur tingkat kepraktisan dilihat dari apakah guru (dan pakarpakar lainnya) mempertimbangkan bahwa materi mudah dan dapat digunakan oleh guru dan siswa. Oleh karena itu, kepraktisan Lembar Kerja Siswa ini diuji coba secara terbatas, dengan instrumen lembar observasi, dan lembar angket yang berupa respon guru dan respon siswa. Tujuan instrumen materi, ringkasan, dan petunjuk-petunjuk pelaksanaan tugas pembelajaran yang mesti dikerjakan peserta didik yang mengacu kepada kompetensi dasar yang harus dicapai.

Dalam pengembangan Lembar Kerja Siswa perlu diterapkan suatu model yaitu model Inquiry. Model Inquiry merupakan rangkaian kegiatan pembelajaran yang menekankan pada proses berpikir secara kritis dan analisis untuk mencari dan menemukan sendiri jawaban dari suatu masalah yang dipertanyakan (Sanjaya, 2006: 194). Pembelajaran menggunakan Lembar Kerja Siswa (LKS) dengan model Inquiry bertujuan untuk siswa mendapatkan pengetahuan dan keterampilan dalam menentukan solusi atau jawaban yang tepat pada masalah pembelajaran matematika.

Pengembangan Lembar Kerja Siswa diperlukan juga suatu model pengembangan yang tepat. Dalam penelitian ini menggunakan model pengembangan yaitu model ADDIE. Adapun tahapan model ADDIE menurut Mulyatiningsih (2011: 179) yang harus ditempuh dalam terdiri dari lima tahap yaitu: yaitu tahap analysis (analisis), tahap design (perencanaan), tahap development (pengembangan), tahap implementation (implementasi), dan tahap evaluation (evaluasi). Dalam pengembangan lembar kerja siswa dibatasi pada tahap implementasi yaitu untuk melihat kepraktisan pembelajaran, serta melihat pemahaman siswa dengan mengggunakan LKS. kepraktisan Lembar Kerja Siswa adalah untuk melihat keterlaksanaan pembelajaran dan keberhasilan.

Salah satu materi yang diambil oleh peneliti adalah materi statistika kelas X. Materi statistika merupakan materi yang mempelajari penyajian data berupa penyajian data tungal dan penyajian data kelompok, pengolahan data, dan penyusunan data berupa table atau diagram/plot.

Berdasarkan uraian diatas penelitian ini menggali bagaimana mengembangkan Lembar Kerja Siswa pada pembelajaran matematika materi statistika yang praktis. Kemudian, tujuan penelitian adalah untuk untuk mengembangkan Lembar Kerja 
Siswa pada pembelajaran matematika materi statistika yang praktis.

\section{Metode Penelitian}

Jenis penelitian ini merupakan penelitian pengembangan (Research and Development) yang bertujuan untuk melihat kualitas produk yang praktis. Produk yang dikembangkan dalam penelitian ini adalah Lembar Kerja Siswa.

Tahap pengembangan Lembar Kerja Siswa ini menggunakan model ADDIE yang merupakan singkatan dari Analysis, Design, Development, Implementation dan Evalutations (Mulyatiningsih, 2011: 179). Tahap pengembangan Lembar Kerja Siswa ini dibatas pada tahap Implementation (Implementasi) yaitu untuk melihat kepraktisan Lembar Kerja Siswa dengan uji coba secara terbatas.

Subjek penelitian ini adalah siswa kelas $\mathrm{X}$ Boga 1 Sekolah Menengah Kejuruan Negeri 2 Tanjungpinang dengan jumlah 33 siswa. Instrumen penelitian ini berupa lembar observasi, lembar angket respon guru, dan lembar angket respon siswa. Angket menggunakan skala likert menurut dengan pilihan jawaban atau respon dalam skala ukur yaitu sangat setuju (ST), setuju (S), tidak setuju (TS) dan sangat tidak setuju (STS).

Teknik analisis data kepraktisan Lembar Kerja Siswa dapat menggunakan rumus oleh Riduan (2009) dalam Ramadhona (2013: 49) sebagai berikut:

$$
\mathrm{p}=\frac{\text { skor item yang diperoleh }}{\text { skor }_{\text {maksimum }}} \times 100 \%
$$

Pengkategorian penilaian lembar observasi, lembar angket guru, dan lembar angket siswa untuk setiap aspek-aspek digunakan untuk Lembar Kerja Siswa pada Tabel 1.

Tabel 1 Kategori Kepraktisan Lembar Kerja Siswa

\begin{tabular}{|c|c|}
\hline $\begin{array}{c}\text { Tingkat Pencapaian } \\
(\%)\end{array}$ & Kategori \\
\hline $81-100$ & Baik Sekali \\
\hline $61-80$ & Baik \\
\hline $41-60$ & Cukup \\
\hline
\end{tabular}

\begin{tabular}{|c|c|}
\hline $21-40$ & Kurang \\
\hline$<21$ & Kurang Sekali \\
\hline
\end{tabular}

(Sumber: Arikunto, dkk (2014:35)

\section{Hasil dan Pembahasan}

Penelitian Pengembangan Lembar Kerja Siswa materi statistika menggunakan model ADDIE, dengan tahap Implementation (Implementasi) untuk melihat kepraktisan Lembar Kerja Siswa. Tahap ini tindakan yang dilakukan adalah uji coba terbatas. Uji coba dilakukan pada tanggal 19 Mei 2017 di kelas X Boga 1 Sekolah Menengah Kejuruan Negeri 2 Tanjungpinang dengan jumlah siswa sebanyak 33 siswa. Penelitian ini dilaksanakan hanya satu pertemuan, dan terakhir pertemuan guru diberikan lembar observasi dan lembar angket respon guru, sedangkan siswa diberikan lembar angket respon siswa.

Lembar observasi bertujuan untuk mengetahui keterlaksanaan pembelajaran yang sesuai dengan Rancangan Perangkat Pembelajaran. Aspek yang diamati pada Lembar observasi sesuai dengan Rancangan Perangkat Pembelajaran (RPP) yang di rancang, yaitu aspek pendahuluan, aspek kegiatan inti, dan aspek penutup.

Hasil lembar obervasi kegiatan pembelajaran menggunakan Lembar Kerja Siswa pada Tabel 2.

Tabel 2 Hasil Lembar Observasi

\begin{tabular}{|c|l|c|c|}
\hline No & \multicolumn{1}{|c|}{ Aspek } & $\begin{array}{c}\text { Persentase } \\
\text { Kepraktisan }\end{array}$ & Kategori \\
\hline 1 & Pendahuluan & 67 & Baik \\
\hline 2 & Kegiatan Inti & 72 & Baik \\
\hline 3 & Penutup & 75 & Baik \\
\hline \multicolumn{2}{|c|}{ Rata-Rata } & 71 & Baik \\
\hline
\end{tabular}

Berdasarkan Tabel 2 hasil lembar observasi terhadap Lembar Kerja Siswa materi statistika pada kategori baik dengan nilai rata-rata $71 \%$. Jadi, dapat disimpulan bahwa lembar observasi terhadap Lembar Kerja Siswa materi statistika dikatakan praktis.

Angket respon guru bertujuan untuk mengetahui keberhasilan pembelajaran. Aspek yang diamati pada angket respon guru adalah aspek 
JURNAL GANTANG. Maret 2018; III(1): 41 - 45

p-ISSN. 2503-0671

e-ISSN. 2548-5547

penggunaan, aspek materi, aspek daya tarik, dan aspek waktu.

Hasil Angket respon guru menggunakan Lembar Kerja Siswa materi statistika pada Tabel 3.

Tabel 3 Hasil Angket Respon Guru

\begin{tabular}{|c|l|c|c|}
\hline No & \multicolumn{1}{|c|}{ Aspek } & $\begin{array}{c}\text { Persentase } \\
\text { Kepraktisan }\end{array}$ & Kategori \\
\hline 1 & Penggunaan & 75 & Baik \\
\hline 2 & Materi & 75 & Baik \\
\hline 3 & Daya Tarik & 75 & Baik \\
\hline 4 & Waktu & 75 & Baik \\
\hline \multicolumn{2}{|c|}{ Rata-Rata } & 75 & Baik \\
\hline
\end{tabular}

Berdasarkan Tabel 3, hasil angket respon guru terhadap Lembar Kerja Siswa materi statistika pada kategori baik dengan nilai rata-rata 75\%. Jadi, dapat disimpulan bahwa angket respon guru terhadap Lembar Kerja Siswa materi statistika dikatakan praktis.

Angket respon siswa bertujuan untuk mengetahui pemahaman siswa. Aspek yang diamati pada angket respon siswa adalah aspek keterampilan, aspek materi, aspek daya tarik, aspek bahasa, dan aspek waktu.

Hasil Angket respon siswa menggunakan Lembar Kerja materi statistika pada Tabel 4.

Tabel 4 Hasil Angket Respon Siswa

\begin{tabular}{|c|l|c|c|}
\hline No & Aspek & $\begin{array}{c}\text { Persentase } \\
\text { Kepraktisan }\end{array}$ & Kategori \\
\hline 1 & Tampilan & 88 & Baik Sekali \\
\hline 2 & Materi & 85 & Baik Sekali \\
\hline 3 & $\begin{array}{l}\text { Daya } \\
\text { Tarik }\end{array}$ & 82 & Baik sekali \\
\hline 4 & Bahasa & 84 & Baik Sekali \\
\hline 5 & Waktu & 83 & Baik sekali \\
\hline \multicolumn{2}{|c|}{ Rata-Rata } & 84 & Baik Sekali \\
\hline
\end{tabular}

Berdasarkan Tabel 4 hasil angket respon siswa terhadap Lembar Kerja Siswa materi statistika pada kategori baik sekali dengan nilai rata-rata $84 \%$. Jadi, dapat disimpulkan bahwa angket respon siswa terhadap Lembar Kerja Siswa materi statistika dikatakan praktis.

Adapun untuk hasil keseluruhan uji coba kepraktisan Lembar Kerja Siswa materi statistika pada Tabel 5 .

Tabel 5. Hasil Keseluruhan Kepraktisan Lembar

\begin{tabular}{|c|l|c|c|}
\hline \multicolumn{5}{|c}{ Kerja Siswa } \\
\hline No & Instrumen & $\begin{array}{c}\text { Persentase } \\
\text { Kepraktisan }\end{array}$ & Kategori \\
\hline 1 & $\begin{array}{l}\text { Lembar } \\
\text { Observasi }\end{array}$ & 71 & Baik \\
\hline 2 & $\begin{array}{l}\text { Angket } \\
\text { Respon } \\
\text { Siswa }\end{array}$ & 84 & $\begin{array}{c}\text { Baik } \\
\text { Sekali }\end{array}$ \\
\hline 3 & $\begin{array}{l}\text { Angket } \\
\text { Respon } \\
\text { Guru }\end{array}$ & 75 & Baik \\
\hline \multicolumn{2}{|c|}{ Rata-Rata } & 77 & Baik \\
\hline
\end{tabular}

Berdasarkan Tabel 5 hasil keseluruhan uji coba kepraktisan Lembar Kerja Siswa materi statistika adalah $77 \%$ dengan kategori baik. Hasil kepraktisan Lembar Kerja Siswa materi statistika diihat pada Gambar 1.

\section{Persentase Kepraktisan}

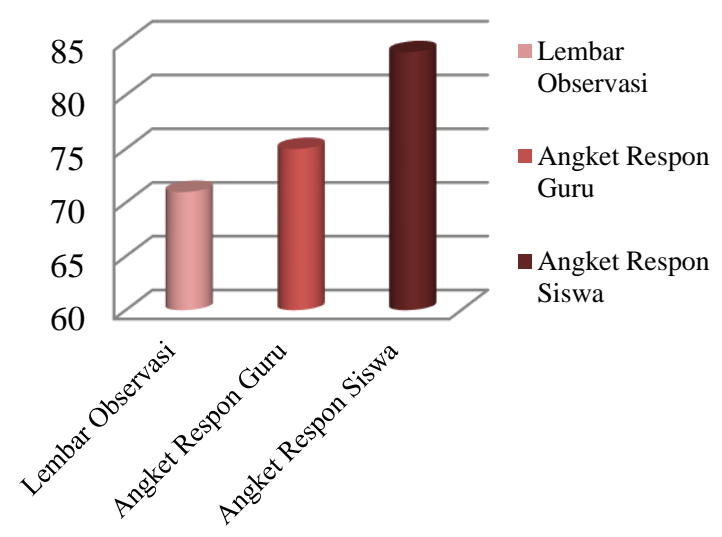

Gambar 1. Persentase Keseluruhan Kepraktisan Lembar Kerja Siswa 
Pada Gambar 5 menunjukkan hasil keseluruhan kepraktisan Lembar Kerja Siswa materi statistika sudah praktis dilihat dari hasil instrument lembar observasi, angket respon guru, dan angket respon siswa.

\section{Penutup}

Berdasarkan hasil proses penelitian yang dilakukan untuk mendapatkan praktikalitas Lembar Kerja Siswa dengan menggunakan model ADDIE (analysis, design, development, implementation, dan evaluation) menghasilkan Lembar Kerja Siswa yang praktis didapatkan dari tiga data, yaitu, pertama data observasi siswa memperoleh rata-rata $71 \%$ dengan kategori baik, kedua data angket respon guru dengan rata-rata $75 \%$ dengan kategori baik, dan ketiga data angket respon siswa dengan rata-rata $84 \%$ dengan kategori baik sekali. Selanjutnya, respon yang diberikan oleh guru dan siswa terhadap data hasil penilaian dari lembar observasi, angket respon guru, dan angket respon siswa. Secara umum tanggapan guru terhadap Lembar Kerja Siswa yang telah digunakan dalam pembelajaran adalah tanggapan guru baik dan tanggapan siswa adalah sangat baik. Hal ini berarti menyatakan Lembar Kerja Siswa yang dikembangkan sudah praktis.

\section{Referensi}

Majid, A. (2013). Perencanaan Pembelajaran: Mengembangkan Standar Kompetensi Guru. Bandung: PT Remaja Rosdakarya

Mulyatiningsih, Endang. (2014). Metode Penelitian Terapan Bidang Pendidikan. Bandung: Penerbit Alfabeta

Prastowo, Andi. (2015). Panduan Kreatif Membuat Bahan Ajar Inovatif: Menciptakan Metode Pembelajaran yang Menarik dan Menyenangkan. Banguntapan Jogjakarta: DIVA Press

Ramadhona, Rezky. (2013). Pengembangan Perangkat Pembelajaran Matematika Berbasis Inquiry Disertai Mind Map Untuk Siswa Kelas Viii Sekolah Menengah Pertama. Tesis tidak diterbitkan. Padang: Pascasarjana Universitas Negeri Padang
Astuti, P., Purwoko, P., \& Indaryanti, I. (2017). Pengembangan LKS Untuk Melatih Kemampuan Berpikir Kritis dalam Mata Pelajaran Matematika di Kelas VII SMP. Jurnal Gantang, 2(2), 145-155.

Rochmad, Rochmad. (2012). Desain Model Pengembangan Perangkat Pembelajaran Matematika. Kreano, Jurnal Matematika Kreatif-Inovatif 3(1): 59-72.

Suharmi Arikunto, dkk. (2014). Evaluasi Program Pendidikan: Pedoman Teoretis Praktis Bagi Mahasiswa Dan Praktis Pendidikan. Jakarta: Bumi Aksara 
JURNAL GANTANG. Maret 2018; III(1): 41 - 45

p-ISSN. 2503-0671

e-ISSN. 2548-5547 